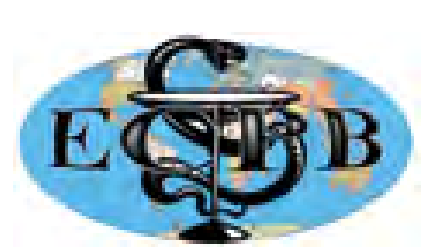

“ЕКСПЕРИМЕНТАЛЬНА ТА КЛІНІЧНА ФІЗІОЛОГІЯ І БІОХІМІЯ” "EXPERIMENTAL AND CLINICAL PHYSIOLOGY AND BIOCHEMISTRY" Науково-практичний журнал/Scientific-practical journal

Наукові статті / Research article ECPB 2018, 4(84): 18-23. https://doi.org/

\title{
The Comparative Study of Vegetotropic Effects of Non-pharmacological Agents in Basal and Acute Stress Conditions in Rats of both Sexes
}

\author{
V.M. FIL ${ }^{1}$, I.-S.S. FLYUNT ${ }^{1}$, O.G. MYSAKOVETS' ${ }^{2}$, O.I. MEL'NYK ${ }^{2}$, \\ H.Y. MATIYISHYN ${ }^{3}$ \\ ${ }^{1}$ Ivan Franko Pedagogical University, Drohobych, Ukraine \\ ${ }^{2}$ Danylo Halytskyi Lviv National Medical University, Lviv, Ukraine \\ ${ }^{3}$ Ukrainian Scientific Research Institute of Transport Medicine, Odesa, Ukraine
}

\section{E-mail: mysakovets@meta.ua}

Introduction. The studies of Truskavets scientific school of balneology and phytotherapy have established an important role in the mechanism of epy physiological and therapeutic action of mineral waters (on the example of water Naftussya) on the autonomic nervous system. First of all, it is the well-known but underestimated fact that the operating principles of mineral waters are not only and even not so many contain electrolytes and trace elements, but to a greater extent various organic substances and microbes that are present in the composition of practically all drinking medicinal waters $[5,8,12,13,30]$. The key is the irritation with electrolytes and organic substances localized in the gastro-intestinal mucosa chemoreceptors of afferent fibers of the vagus, on the one hand, and the microbes and the same organic substances of TL-receptors of immunocytes (mainly macrophages) of GALT (Gut-associated lymphoid tissue). The activation of the TL-receptors of the immunocytes results in the release of cytokines which through the mediation of chemosensitive glomus cells in paraganglia also irritate the vagus terminals. The impulses are first applied to the nucleus tractus solitarius of the brain stem and then to the integrative set point center, from which they diverge to the nucleus ambiguus and rostral ventrolateral medulla as vagal and sympathetic stem centers respectively [19,32]. As a result, depending on the reactivity, either the sympathetic or vagal tone increases, which is accompanied by polyvariant changes in the parameters of immunity, hemodynamics, cholekinetics, gastric and pancreatic secretion and levels of hormones in the blood [7,12,14-17,19,25-29,32-36].

In the tract of Pomyarky in Truskavets resort the water "Truskavetska", being extracted from the wells is almost identical to Naftussya with the composition of the electrolytes and the gross organic carbon content, but artificially deprived of microflora because it is packed in polyethylene bottles and is sold as table water for daily use. It is believed that this water is not physiologically active and curative, but we have not been able to find publications about its physiological effect. At the same time, "Truskavetska" water becomes active after enriching it with an extract of aloe [9-11] and polyphenolic preparation "Enomelanin" [22,37].

The vegetative regulation in these studies was not fully investigated, which determined the aim of our research.

Materials and methods. The research was carried out on females white Wistar rats T5 (body mass mean $=220 \mathrm{~g}$; SD $=28 \mathrm{~g}$ ). In order to minimize the effect of post-stress changes in the vegetative status of individual resistance

(c) Fil V.M., Flyunt I.-S.S., Mysakovets' O.G., 2018 
to hypoxia and physical endurance [31], all animals were originally subjected to the classical Berezovskyi test [4] and in a week to the swimming test $[1,6]$, respectively. Then 5 groups of rats were created which were of similar sex, body mass, time of occurrence of second agonal inspiration and duration of swimming with the cargo (5\% from the body mass) to the exhaustion of both averages and their dispersion. After a week's restoration 10 animals of the first group remained relatively intact while others 38 rats received a course of water loads through a tube at a dose $2 \%$ of body mass once daily during seven days. The experimental rats were treated with tap water as a control group, table water "Truskavetska" taken from the bottle as well as "Enomelanin" (10\% paste dissolved in distilled water or "Truskavetska" water of $0.04 \%$ ). A day after the end of the course, samples of peripheral blood (through a cut tail) were taken to analyze leukocytogram (will not be discussed in this article) and then recorded under light ether anesthesia for 15-20 sec ECG in standard lead II (introducing needle electrodes subcutaneously) to determine parameters of heart rate variability (HRV) [2]. Then animals of test groups were subjected to water immersion restraint stress by Nakamura's method [23], modified by I.L. Popovych [25], according to which the duration of staying of rats in cold water $\left(\mathrm{t}=20-21^{\circ} \mathrm{C}\right)$ was reduced from 8 to 4 hours. The day after acute stress the blood was taken and the ECG was recorded again.

Results and discussion. The integral state of vegetative regulation was estimated by Baevskiy's Stress Index [2], which was calculated by the formula modified by I.L. Popovych [36]: Stress Index $=(\mathrm{AMo} / 2 \cdot \mathrm{Mo} \cdot \mathrm{MxDMn})^{1 / 3}$.

It has been revealed (Fig. 1) that the weekly consumption of ordinary water has not affected the basal stress index at all, whereas water "Truskavetska" has caused a slight tendency to increase it. The water enriched with polyphenols from "Enomelanin" has alleviated this trend. The similar effect has occurred with a $0.04 \%$ solution of "Enomelanin" in distilled water, so both groups were combined.

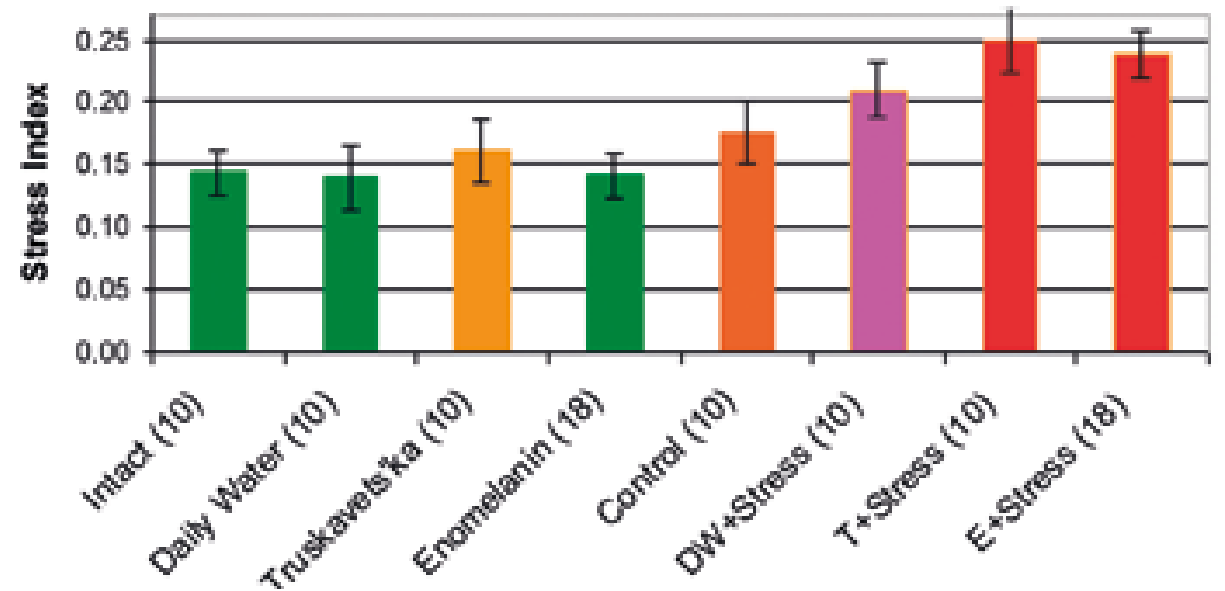

Fig. 1. Stress Index (Mean $\pm \mathrm{SE}$ ) alone and in the day after acute stress after a weekly use of non-medicated means

Blood sampling from the tail slightly increases the level of stress index, which is naturally considered to be an unpleasant procedure. It has been expected that there is a significant increase in the stress index in the day after 4 hours of acute stress in rats which used water daily, while after using the water "Truskavetska" the severity of stress has increased. "Enomelanin" has not shown any stress limiting effect.

With the aim of a single-scale evaluation of individual components of vegetative regulation, they are listed in the Z-units (Table 1, Fig. 2). It has been found out that concerning a stable Stress Index and sympathetic tone, 
there is a tendency towards increasing of vagal influences after fresh water consumption, which is offset by a sympathetic shift of humoral effects on the heart rhythm.

Table 1

Vegetotropic effects of non-medicated means

\begin{tabular}{|c|c|c|c|c|c|c|c|}
\hline Groups (n) & $\begin{array}{l}\text { Para- } \\
\text { meters }\end{array}$ & $\begin{array}{l}\text { Popovych's } \\
\text { Stress Index, } \\
\text { units }\end{array}$ & $\begin{array}{c}\text { Amplitude } \\
\text { of Moda } \\
\text { HRV, \% }\end{array}$ & $\begin{array}{l}\text { MxDMn } \\
\text { HRV, } \\
\text { mcec }\end{array}$ & $\begin{array}{l}\text { Moda, } \\
\text { HRV } \\
\text { msec }\end{array}$ & $\begin{array}{l}\text { Hypo- } \\
\text { xic } \\
\text { test, } \\
\text { sec }\end{array}$ & $\begin{array}{l}\text { Swim- } \\
\text { ming, } \\
\text { test, } \\
\text { min }\end{array}$ \\
\hline Intact (10) & $\begin{array}{l}\mathrm{M} \pm \mathrm{SE} \\
\mathrm{Z} \pm \mathrm{SE}\end{array}$ & $\begin{array}{l}0.144 \pm 0.018 \\
0\end{array}$ & $\begin{array}{l}43.4 \pm 5.1 \\
0\end{array}$ & $\begin{array}{l}59 \pm 10 \\
0\end{array}$ & $\begin{array}{l}203 \pm 23 \\
0\end{array}$ & $\begin{array}{l}134 \\
\pm 26\end{array}$ & $19 \pm 6$ \\
\hline $\begin{array}{l}\text { Daily Water } \\
(10)\end{array}$ & $\begin{array}{l}\mathrm{M} \pm \mathrm{SE} \\
\mathrm{Z} \pm \mathrm{SE}\end{array}$ & $\begin{array}{l}0.139 \pm 0.027 \\
-0.08 \pm 0.47 \\
\end{array}$ & $\begin{array}{l}42.4 \pm 7.6 \\
-0.06 \pm 0.47 \\
\end{array}$ & $\begin{array}{l}89 \pm 24 \\
+0.60 \pm 0.47 \\
\end{array}$ & $\begin{array}{l}186 \pm 18 \\
-0.22 \pm 0.24 \\
\end{array}$ & $\begin{array}{l}130 \\
\pm 25 \\
\end{array}$ & $18 \pm 4$ \\
\hline $\begin{array}{l}\text { "Truskavetska" } \\
\text { Water (10) }\end{array}$ & $\begin{array}{l}\mathrm{M} \pm \mathrm{SE} \\
\mathrm{Z} \pm \mathrm{SE}\end{array}$ & $\begin{array}{l}0.161 \pm 0.024 \\
+0.30 \pm 0.42\end{array}$ & $\begin{array}{l}57.4 \pm 9.8 \\
+0.87 \pm 0.61\end{array}$ & $\begin{array}{l}70 \pm 24 \\
+0.22 \pm 0.47\end{array}$ & $\begin{array}{l}187 \pm 16 \\
-0.22 \pm 0.22\end{array}$ & $\begin{array}{l}128 \\
\pm 22\end{array}$ & $18 \pm 2$ \\
\hline $\begin{array}{l}\text { "Enomelanin" } \\
\text { with DW or } \\
\text { TW (18) }\end{array}$ & $\begin{array}{l}\mathrm{M} \pm \mathrm{SE} \\
\mathrm{Z} \pm \mathrm{SE}\end{array}$ & $\begin{array}{l}0.141 \pm 0.019 \\
-0.04 \pm 0.33\end{array}$ & $\begin{array}{l}45.5 \pm 6.2 \\
+0.13 \pm 0.28\end{array}$ & $\begin{array}{l}95 \pm 19 \\
+0.71 \pm 0.38\end{array}$ & $\begin{array}{l}179 \pm 8 \\
-0.32 \pm 0.10^{*}\end{array}$ & $\begin{array}{l}136 \\
\pm 14\end{array}$ & $19 \pm 3$ \\
\hline $\begin{array}{l}\text { Daily Water } \\
\text { + blood } \\
\text { sampling (10) }\end{array}$ & $\begin{array}{l}\mathrm{M} \pm \mathrm{SE} \\
\mathrm{Z} \pm \mathrm{SE}\end{array}$ & $\begin{array}{l}0.175 \pm 0.025 \\
0\end{array}$ & $\begin{array}{l}53.7 \pm 7.5 \\
0\end{array}$ & $\begin{array}{l}47 \pm 14 \\
0\end{array}$ & $\begin{array}{l}172 \pm 10 \\
0\end{array}$ & & \\
\hline $\begin{array}{l}\text { Daily Water } \\
+ \text { Stress (10) }\end{array}$ & $\begin{array}{l}\mathrm{M} \pm \mathrm{SE} \\
\mathrm{Z} \pm \mathrm{SE}\end{array}$ & $\begin{array}{l}0.210 \pm 0.021 \\
+0.47 \pm 0.29\end{array}$ & $\begin{array}{l}58.0 \pm 5.5 \\
+0.18 \pm 0.23 \\
\end{array}$ & $\begin{array}{l}29.5 \pm 7.0 \\
-0.39 \pm 0.16^{*}\end{array}$ & $\begin{array}{l}155 \pm 9 \\
-0.56 \pm 0.30 *\end{array}$ & & \\
\hline $\begin{array}{l}\text { "Truskavetska" } \\
\text { + Stress (10) }\end{array}$ & $\begin{array}{l}\mathrm{M} \pm \mathrm{SE} \\
\mathrm{Z} \pm \mathrm{SE}\end{array}$ & $\begin{array}{l}0.250 \pm 0.026 \\
+1.00 \pm 0.35^{*}\end{array}$ & $\begin{array}{l}74.3 \pm 6.7 \\
+0.87 \pm 0.28 *\end{array}$ & $\begin{array}{l}26 \pm 11 \\
-0.47 \pm 0.24\end{array}$ & $\begin{array}{l}159 \pm 11 \\
-0.42 \pm 0.36\end{array}$ & & \\
\hline $\begin{array}{l}\text { "Enomelanin" } \\
+ \text { Stress (18) }\end{array}$ & $\begin{array}{l}\mathrm{M} \pm \mathrm{SE} \\
\mathrm{Z} \pm \mathrm{SE}\end{array}$ & $\begin{array}{l}0.239 \pm 0.019 \\
+0.86 \pm 0.25^{*}\end{array}$ & $\begin{array}{l}69.0 \pm 4.4 \\
+0.64 \pm 0.19 *\end{array}$ & $\begin{array}{l}22 \pm 3 \\
-0.56 \pm 0.08^{*}\end{array}$ & $\begin{array}{l}163 \pm 6 \\
-0.31 \pm 0.19\end{array}$ & & \\
\hline
\end{tabular}

The water "Truskavetska" has increased the sympathetic tone due to, apparently, organic substances such as alkylphenols, alkylbenzenes or alkylnaphthalenes, in particular [8]. However, polyphenols in the composition of "Enomelanin" have a vagotonic effect, which contradicts their ability to inhibit catechol-o-methyl transferase [3,21].

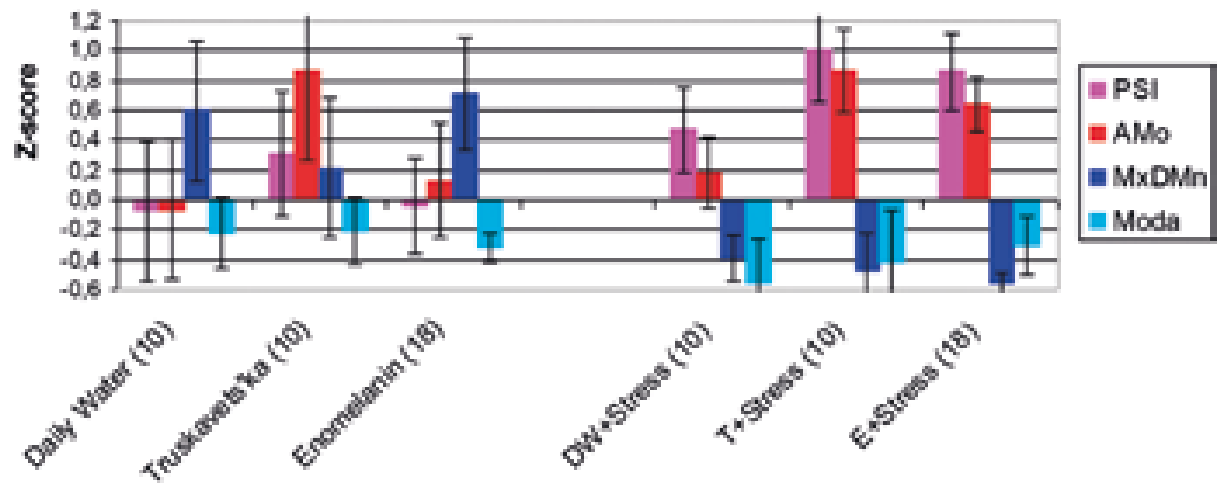

Fig.2. Changes in Stress Index, sympathetic and vagal tone as well as in humoral channel in basal and acute stress conditions

The next day after the acute stress, there was only a tendency to increase the sympathetic tone in combination with a significant reduction in the vagus tone and sympathetic shift in the humoral channel of regulation. The water "Truskavetska" has not affected the latter, but significantly potentiated the sympathetic effect of stress. "Enomelanin" has acted in the same way. 
Conclusion. To sum up, the vegetotropic effect of polyphenols is conditioned by some factors that accompany the stress reaction.

Conformity to ethical standards. Experiments on animals have been carried out in accordance with the provisions of the Helsinki Declaration of 1975, revised and supplemented in 2002 by the Directives of the National Committees for Ethics in Scientific Research.

The conducting of experiments was approved by the Ethics Committee of the Danylo Halytskyi Lviv National Medical University. The modern rules for the maintenance and use of laboratory animals complying with the principles of the European Convention for the Protection of Vertebrate Animals used for scientific experiments and needs are observed (Strasbourg, 1985).

Рекомендовано до друку колісією з біоетики

\section{REFERENCES (ПОСИЛАННЯ)}

1. Alyeksyeyev OI, Popovych IL, Panasyuk YeM, Barylyak LG, Sarancha SM, Shumakov $M F$. Adaptogens and Radiation. Kyiv: Nauk. Dumka, 1996. 126 p. [Ukrainian]

2. Baevskiy RM, Kirillov OI, Kletskin SZ. Mathematical Analysis of Changes in Heart Rate by Stress. Moskva: Nauka, 1984. 221 p. [Russian]

3. Baraboy VA. Biological Effect of Plant Phenolic Compounds. Kyiv: Naukova dumka. 1976. 260 p. [Russian]

4. Berezovs'kyi VYa. The personality traits in reaction to hypoxia. Fiziologichnyi Zhurnal. 1975;21(3):371-6. [Ukrainian]

5. Bilas VR, Popovych IL. Role of microflora and organic substances of water Naftussya in its modulating influence on neuroendocrine-immune complex and metabolism. Medical Hydrology and Rehabilitation. 2009;7(1):68-102. [Ukrainian]

6. Brekhman II. Eleuterococc. Leningrad: Nauka, 1968. 186 p. [Russian]

7. Chebanenko OI, Chebanenko LO, Popouych IL. Multivariety Balneoeffects of Factors Spa Truskavets' and their Forecast. Kyiv: UNESCO-SOCIO, 2012. 496p. [Ukrainian]

8. Dats'ko OR, Bubnyak AB, Ivassivka SV. Organic component of mineral water Naftussya. Development of the concept of its composition and origin. Medical Hydrology and Rehabilitation. 2008;6(1):168-174. [Ukrainian]

9. Fil' VM. Physiological activity of the healing drink "Truskavetska crystalline, enriched aloe". Message 1: Adaptogenic, metabolic and immunotropic effects. Medical Hydrology and Rehabilitation. 2006;4(3):79-102. [Ukrainian]

10. Fil' VM. Physiological activity of the healing drink "Truskavetska crystalline, enriched aloe". Message 2: Choleretic-absorption, excretory-depuration and adaptogenic effects. Medical Hydrology and Rehabilitation. 2006;4(4):53-63. [Ukrainian]

11. Fil' VM. Physiological activity of the healing drink "Truskavetska crystalline, enriched aloe". Message 3: Antioxenobiotic, myotropic and gastrotropic effects. Medical Hydrology and Rehabilitation. 2007; 5(1):26-31. [Ukrainian]

12. Hrytsak YaL, Mysakovets' OG, Mel'nyk OI, Barylyak LG. Features of immunity by various constellations of principal adaptation hormones and autonomous regulation in rats. Experimental and Clinical Physiology and Biochemistry. 2017;4(80):13-23.

13. Ivassivka SV, Bubnyak AB, Kovbasnyuk MM, Popovych IL. Genesis and role of phenols in waters from Naftussya layer. In: Problems of pathology in experiment and clinic. Scientific works of Drohobych Medical Institute. Vol. XV. Drohobych. 1994;6-11. [Ukrainian]

14. Ivassivka SV, Kovbasnyuk MM, Bubnyak AB, Sovyak DH. Monitoring of the activity of the autochthonous microflora of the water Naftusya Truskavets field and its interconnections with the organic factors of this water and the intensity of precipitation. Medical Hydrology and Rehabilitation. 2010;8(2):57-78. [Ukrainian]

15. Kozyavkina OV. Post-stress changes in neuroendocrine status and metabolism in rats with different types of initial vegetative homeostasis induced by bioactive water Naftusysa. Medical Hydrology and Rehabilitation. 2009;7(1):42-50. [Ukrainian]

16. Kozyavkina $O V$. State of post-stress parameters of vegetative homeostasis and endocrine, metabolic and immune status as well as the relationship between them in rats with alternative types of precursor vegetative homeostasis induced by bioactive water Naftussya. Medical Hydrology and Rehabilitation. 2009;7(2):40-56. [Ukrainian]

17. Kozyavkina $O V$. Vegetotropic effects of bioactive water Naftussya in male rats and their endocrine, electrolyte and immune accompaniments. Medical Hydrology and Rehabilitation. 2012;10(3):65-92. [Ukrainian]

18. Kozyavkina OV, Barylyak LG. Ambivalent vegetotropic effects of bioactive water Naftussya and opportunity of their forecasting at rats. Medical Hydrology and Rehabilitation. $2008 ; 6(3): 123-7$. 
19. Kozyavkina OV, Kozyavkina NV, Gozhenko OA, Gozhenko AI, Barylyak LG, Popovych IL. Bioactive Water Naftussya and Neuro-Endocrine-Immune Complex. Kyiv: UNESCO-SOCIO, 2015. 349 p. [Ukrainian]

20. Kozyavkina OV, Popovych $I L$, Zukow W. Immediate vegetotropic effects of bioactive water Naftussya and their neuro-endocrine-immune accompaniment in healthy men. Journal of Health Sciences. 2013;3(5):391-408.

21. Lupandin $A V$. On the role of catecholaminergic synapses in the mechanism of formation of adaptation with the participation of polyphenol adaptogens. Fiziological Zhurnal. SSSR. 1989;75(8):1082-8. [Russian]

22. Matiyishyn GYo, Huchko BYa, Bilas VR, Baranyak NB, Koval'chuk GYa, Ivassivka AS. Investigation of adaptogenic properties of polyphenolic preparation "Enomelanin". Medical Hydrology and Rehabilitation. 2008;6(3):69-73. [Ukrainian]

23. Nakamura J, Takada S, Ohtsuka $N$, Heya T. An assessment of gastric ulcers in vivo: enhancement of urinary recovery after oral administration of phenolsulfonphtalein in rats. Journal of Parmacobio Dynamics. 1984;7(7):485-91.

24. Panasyuk YM, Levkut LH, Popovych IL, Alekseyev OI, Kovbasnyuk MM, Balanovskyi VP. Experimental study of adaptogenic properties of "Crimean" balm. Fiziological Zhurnal. 1994;40(34):25-30. [Ukrainian]

25. Popovych IL. The factor and canonical analysis parameters of neuro-endocrine-immune complex, metabolism and erosive-ulcerose injuries of mucous stomach at rats in conditions of acute water immersing stress. Medical Hydrology and Rehabilitation. 2007;5(2):68-80. [Ukrainian]

26. Popovych IL. Information effects of bioactive water Naftyssya in rats: modulation entropic, prevention desynchronizing and limitation of disharmonizing actions water immersion stress for information components of neuro-endocrine-immune system and metabolism, which correlates with gastroprotective effect. Medical Hydrology and Rehabilitation. 2007;5(3):50-70. [Ukrainian]

27. Popovych IL. Bioactive water Naftyssya in general like ginseng limits, negates, reverses neuro-hormonal, metabolic and immune pathogens manifestations and strengthens sanogens manifestations acute stress in rats without impacting significantly on performance, not subordinates stress action. Medical Hydrology and Rehabilitation. 2007;5(4):7-29. [Ukrainian]

28. Popovych IL. Influence of the course on the use of bioactive water Naftussya on vegetative regulation in rats in basal and post-stress periods. Medical Hydrology and Rehabilitation. 2008;6(2):79-83. [Ukrainian]

29. Popovych IL. Immediate responses of the autonomic nervous system to the balneofactors, their neuro-endocrine-immune accompaniments and predictors. Experimental and Clinical Physiology and Biochemistry. 2018;1(81):11-26.

30. Popovych IL, Ivassivka SV. Role of organic substances of water Naftussya in its physiological activity. Medical Hydrology and Rehabilitation. 2009;7(2):6-26. [Ukrainian]

31. Popovych IL, Ivassivka SV, Barylyak LG, Fil' VM, Korolyshyn TA, Shologin AI et al. Features of stress-induced changes in the gastric mucosa, neuroendocrine-immune complex and metabolism in rats with varying resistance to hypoxia. Medical Hydrology and Rehabilitation. 2010;8(2):96-109. [Ukrainian]

32. Popovych IL, Vis'tak HI, Gumega MD, Ruzhylo SV. Vegetotropic Effects of Bioactive Water Naftussya and their Endocrine-Immune, Metabolic and Hemodynamic Accompaniments. Kyiv: UNESCO-SOCIO, 2014. 163 p. [Ukrainian]

33. Sydoruk NO, Gozhenko AI, Zukow W. Modulating effects of bioactive water Naftussya from layers Truskavets' and Pomyarky on neuro-endocrine-immune complex and metabolism at rats exposed to acute stress. Journal of Education, Health and Sport. 2016;6(11):715-30.

34. Sydoruk NO, Zukow $W$. Comparative investigation of immediate effects on neuroendocrine-immune complex of bioactive water Naftussya from layers Truskavets', Pomyarky and Skhidnyts'a. Communication 1. Generic effects. Journal of Education, Health and Sport. 2016;6(8):85-101.

35. Sydoruk NO, Zukow W, Yanchij RI. Integrated quantitative assessment of changes in neuro-endocrine-immune complex and metabolism in rats exposed to acute cold-immobilization stress. Journal of Education, Health and Sport. 2016;6(9):724-35.

36. Vis'tak HI, Popovych IL. Vegetotropic effects of bioactive water Naftussya and their endocrine and immune support in female rats. Medical Hydrology and Rehabilitation. 2011;9(2):3957. [Ukrainian]

37. Zherebin YuL, Bondarenko NA, Makan SYu. Pharmacological properties of enomelanic pigments. Reports of the Academy of Sciences of the Ukrainian SSR. Series B. 1984;3:64-68. [Russian] 


\title{
RESEARCH ARTICLE
}

\section{The Comparative Study of Vegetotropic Effects of Non- pharmacological Agents in Basal and Acute Stress Conditions in Rats of both Sexes}

\author{
V.M. FIL', I.-S.S. FLYUNT', O.G. MYSAKOVETS', O.I. MEL'NYK', \\ H.Y. MATIYISHYN ${ }^{3}$ \\ 1 Ivan Franko Drohobych Pedagogical University, Ukraine \\ 2 Danylo Halytskyi Lviv National Medical University, Ukraine \\ 3 Ukrainian Scientific Research Institute of Transport Medicine, Odesa, Ukraine \\ E-mail: mysakovets@meta.ua
}

Background. In the tract of Pomyarky in Truskavets resort the water "Truskavetska", being extracted from the wells, is almost identical to Naftussya with the composition of the electrolytes and the gross organic carbon content, but artificially deprived of microflora. The purpose of this study is to investigate the vegetotropic effect of this water in comparison with the polyphenolic preparation "Enomelanin" as a possible water ameliorator.

Material and methods. The experiment was conducted on 48 Wistar rats which were divided into 5 groups of similar sex, body mass, hypoxic and swimming tests. 10 animals of the first group remained relatively intact while others 38 rats received a course of water loads through a tube at a dose $2 \%$ of body mass once daily during seven days. The experimental rats were treated with tap water as a control group, table water "Truskavetska" taken from the bottle as well as "Enomelanin" (10 \% paste dissolved in distilled water or "Truskavets"ka" water of $0,04 \%$ ). One day after the end of the course the ECG was recorded under light ether anesthesia to determine parameters of heart rate variability. Then animals of test groups were subjected to water immersion restraint stress. The day after acute stress the ECG was recorded again.

Results. The weekly consumption of ordinary water has not affected the basal stress index at all, whereas water "Truskavetska" has caused a slight tendency to increase it. The water enriched with polyphenols from "Enomelanin" has alleviated this trend. A similar effect has been observed with a $0,04 \%$ solution of "Enomelanin" in distilled water. In the control group after acute stress there has been a tendency to increase the sympathetic tone in combination with a significant reduction in the vagus tone and some sympathetic shift in the humoral channel of regulation. The water "Truskavet'ka" has not affected the latter, but significantly potentiated the sympathetic effect of stress. "Enomelanin" has acted in a similar way.

Conclusion. It can be concluded that the vegetotropic effect of polyphenols is conditioned by some factors that accompany the stress reaction.

Key words: heart rate variability, water "Truskavetska", "Enomelanin", acute stress, rats. 